\title{
Journalism that tells the future: possibilities and journalistic scenarios for augmented reality
}

\author{
Santiago Tejedor-Calvo; Luis M. Romero-Rodríguez; Andrés-José Moncada- \\ Moncada; Mariana Alencar-Dornelles
}

Nota: Este artículo se puede leer en español en:

http://www.elprofesionaldelainformacion.com/contenidos/2020/nov/tejedor-romero-moncada-alencar_es.pdf

How to cite this article:

Tejedor-Calvo, Santiago; Romero-Rodríguez, Luis M.; Moncada-Moncada, Andrés-José; Alencar-Dornelles, Mariana (2020). "Journalism that tells the future: possibilities and journalistic scenarios for augmented reality". Profesional de la información, v. 29, n. 6, e290602.

https://doi.org/10.3145/epi.2020.nov.02

Manuscript received on $23^{\text {rd }}$ October 2020 Accepted on $03^{\text {rd }}$ November 2020

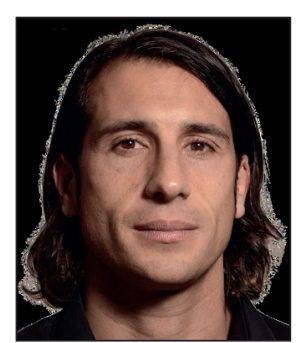

Santiago Tejedor-Calvo $\square$ https://orcid.org/0000-0002-5539-9800

Universitat Autònoma de Barcelona Departamento de Periodismo y Ciencias de la Comunicación Campus UAB, Edifici I 08193 Bellaterra (Barcelona), Spain santiago.tejedor@uab.cat

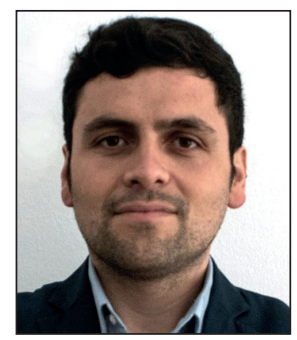

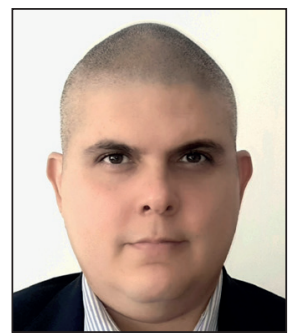

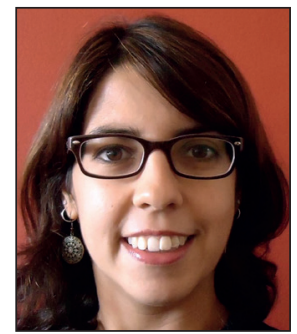

Luis M. Romero-Rodríguez https://orcid.org/0000-0003-3924-1517

Universidad Espíritu Santo ESAI Business School, Ecuador Universidad Rey Juan Carlos Camino del Molino, $\mathrm{s} / \mathrm{n}$. 28943 Fuenlabrada (Madrid), Spain luis.romero@urjc.es

\section{Mariana Alencar-Dornelles} https://orcid.org/0000-0003-2839-9298

Fundación Universitaria Iberoamericana Programa Doctorado Industrial Universitat Autònoma de Barcelona Paseo García Faria, 29 08005 Barcelona, Spain mdornelles@gmail.com

\section{Abstract}

The Gartner Hype Cycle for Emerging Technologies highlights "augmented human technologies" as one of their emerging trends, while the Future Today Institute alludes to the potential of extended reality (digitally manipulated environments encompassing virtual and augmented reality) for the development of new applications with great informative value. Based on this, the current study brings together in-depth interviews with experts who analyze the possibilities of augmented reality (AR) in journalism, including its weaknesses and some proposals for new journalistic scenarios. The study concludes that, according to experts, the use of AR in daily systems and applications is key to establishing this technology. In addition, experts stress the need to carry out sociological and ethical studies of its impact, as well as experimental research on the use of augmented senses in humans, including both visual and haptic augmentation and hearing.

\section{Keywords}

Augmented reality; AR; Technology; Information technologies; Journalism; Immersion; Immersive journalism; Trends.

\section{Funding}

This article is supported by Pla de Doctorats Industrials de la Secretaria d'Universitats i Recerca del Departament d’Empresa i Coneixement de la Generalitat de Catalunya 


\section{Introduction}

"Augmented human technologies," designed to improve the cognitive and physical parts of the body, are one of the five emerging technology trends of 2020 (Image 1), according to the Gartner hype cycle for emerging technologies (Panetta, 2019). In its Trends report for entertainment, media \& technology, the Future Today Institute highlights the communicative potential of augmented reality (AR), especially with the eruption of $5 \mathrm{G}$ technology (FTI, 2020). Journalism will be challenged with taking advantage of AR's potential in designing and producing new content and formats.

$A R$ can address every human sense of perception. However, the most widespread variety of this is the representation of virtual visual information inserted into a real environment (Maquillón-Sánchez; Mirete; Avilés, 2017). From its inception to the present day, the conceptual reflection around this concept has been constant. In 1994, engineers Paul Milgram and Fumio Kishino coined the concept of a "virtuality continuum," referring to the mixing of objects for the purpose of display in a context where a real environment is complemented by computer-generated virtual objects (Milgram; Kishino, 1994). Azuma (1997) contributed to this combination of reality and virtuality with the addition of the interactive component, the real-time element, and three-dimensional (3D) technology. Shortly thereafter, Raskar, Welch, and Fuchs (1998) conceptualized a spatial augmented reality that allowed the integration of virtual images into physical environments beyond the user's field of vision. The works of Yoon and Tilanka (2015) introduced aspects related to the impact of AR on communicational design. The complexity of this technology was classified into levels ranging from 0 to 3 (Prendes-Espinosa, 2015), with an increasing degree of immersion:

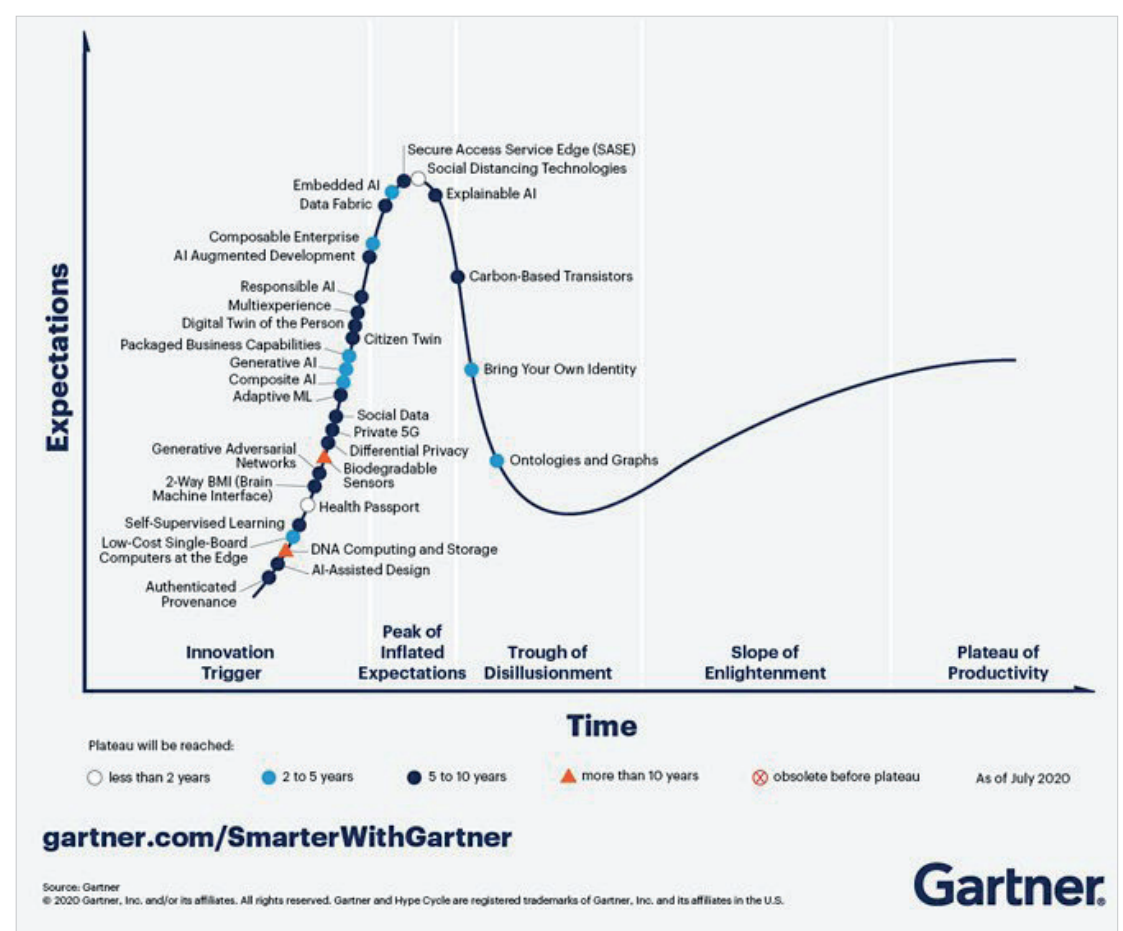

Image 1. Hype cycle for emerging technologies. Source: Gartner (2020).

Table 1. Augmented reality (AR) levels

\begin{tabular}{|l|l|}
\hline \multicolumn{1}{|c|}{ Level } & \multicolumn{1}{c|}{ Characteristics } \\
\hline $\begin{array}{l}\text { Level 0: } \\
\text { physical world hyperlinking }\end{array}$ & $\begin{array}{l}\text { Use of barcodes, 2D codes (such as QRs), or image recognition. At this level, the codes are hyperlinks to } \\
\text { other content. There is no 3D registration or marker tracking. }\end{array}$ \\
\hline $\begin{array}{l}\text { Level 1: } \\
\text { marker-based AR }\end{array}$ & \begin{tabular}{l} 
Configured by 2D pattern recognition or 3D object recognition. \\
\hline $\begin{array}{l}\text { Level 2: } \\
\text { marker-less AR }\end{array}$
\end{tabular} \\
\hline $\begin{array}{l}\text { Operation based on the use of GPS, compasses, or accelerometers of electronic devices. It can determi- } \\
\text { ne the situation and orientation, and can superimpose points of interest onto real-world images. }\end{array}$ \\
\hline
\end{tabular}

Source: Prendes-Espinosa (2015).

Studies have identified three concepts: virtual, augmented, and mixed reality. Virtual reality is conceived as an artificial environment created such that the user feels part of it. Augmented reality is superimposed onto the reality of the user's objects or situation, artificially generated by means of modeling systems, digital animation, or 3D graphics. Finally, mixed reality combines artificially created content with the physical world using holograms that are projected into the context of the user with interactive options (Montoya, 2018; Muñoz-Saavedra; Miró-Amarante; Domínguez-Morales, 2020). Mixed, or extended, reality encompasses environments that are generated, enhanced, or manipulated using digital technology (Flavián; Ibáñez-Sánchez; Orús, 2019). This concept, which encompasses virtual reality (VR) and augmented reality (AR), has experienced great development within various sectors of the industry through various technological developments (Webb, 2018; 2019). The combination that makes AR content real and virtual is what differentiates it from VR, which is focused exclusively on non-real scenarios through immersive proposals supported by external devices such as glasses, helmets, or gloves (Parra-Valcarce; Edo-Bolós; Marcos-Recio, 20017). 
AR is characterized by complementing our sensory perception of the world with digital elements that are accessible through technological devices (Telefónica, 2011). These types of technological developments that connect virtual content with real environments (Azuma, 2017) have great potential for the generation of journa-

listic content. The potential convergence enabled by AR between visual, audiovisual, photographic, infographic, and 2D or 3D content enriched by interactivity (Meneses-Fernández; Martín-Gutiérrez, 2016) opens up numerous possibilities for the journalistic narrative. The superposition, in real time, of images, bookmarks, and other virtual information resources has enabled the emergence of immersive, or 360, journalism. As of 2015 (Benítez-de-Gracia; Herrera-Damas, 2018), this type of journalism had evolved to achieve wide acceptance among users under 24 years of age, demonstrating great solvency in the coverage of social issues (Mañas-Viniegra; Veloso; Sierra-Sánchez, 2020).

Since 1963, when the Daily Oklahoma incorporated a computer (IBM 1620 computer) into a newsroom (Tejedor-Calvo, 2006), technology has driven numerous transformations in journalism that have altered the conception and type of content. Various authors (López-García; Pereira-Fariña, 2010; Domínguez-Martín, 2012a; Peñafiel-Saiz, 2016; Larrondo-Ureta, 2016; López-Hidalgo, 2016; Caswell; Dörr, 2017; Crusafon, 2017; Veel, 2018; Vaz; Tejedor-Calvo, 2019) have investigated these new journalistic formats and possibilities that derive from the process of convergence and hybridization between technology and communication. On the other hand, 360 journalism has been the subject of numerous works that have pointed out the amalgam of possibilities of immersion at the narrative level (De-la-Peña et al., 2010; Domínguez-Martín, 2012b; Kool, 2016; Guizzo-da-Rocha, 2016; Aronson-Rath et al., 2017) by granting a more leading role to the user (Vázquez-Herrero; López-García, 2016; Pérez-Seijo, 2017; Watson, 2017).

Transmedia logic (Jenkins, 2008) has promoted the convergence, mixture, and hybridization of formats and media, enabling the creation of new informational worlds (Galeano, 2018) based on seven main principles: extension versus depth, continuity versus multiplicity, immersion versus extraction, construction of the world, seriality, subjectivity, and performance. AR offers a prolific setting for the development of communication and journalistic projects (Stein; Shew, 2019). Esquire magazine applied $A R$ in 2008 when it used electronic ink on their October cover with the slogan "The $21^{\text {st }}$ Century Begins Now," and on 9 November 2009, it featured Robert Downey Jr. sitting on a QR code with instructions inside on how to activate and interact with the content. In 2010, Wallpaper* magazine featured a work by designer Jørund Blikstad on its cover, allowing interaction with 3D content. On 29 October 2017, Time magazine dedicated its cover to Ethiopian boy Mohamad Nassir and, through the LifeVR application, allowed readers to navigate videos, infographics, and anima-

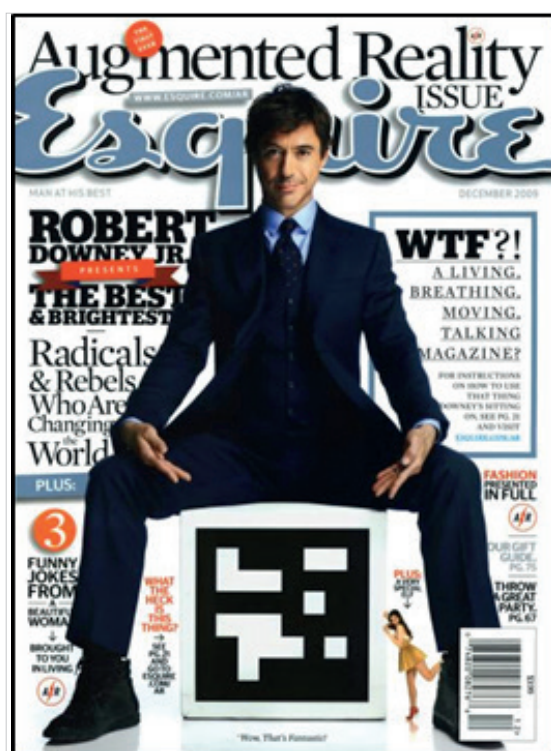

https://www.esquire.com

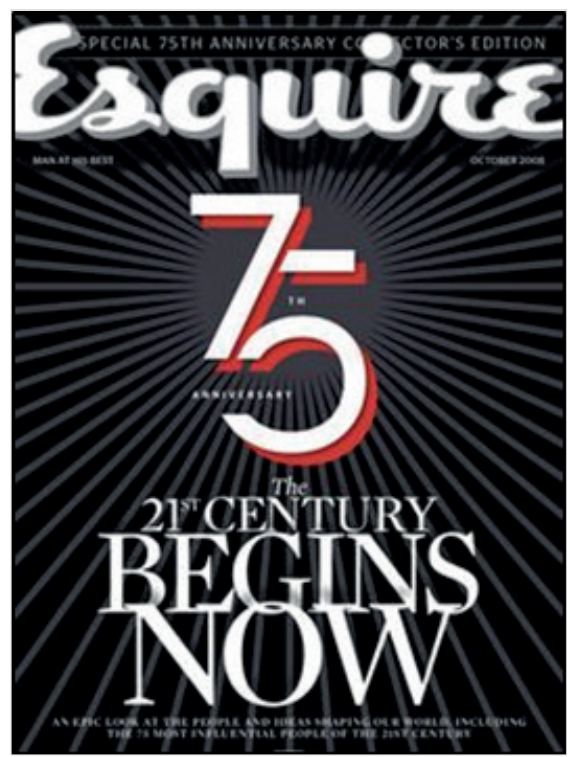

https://www.esquire.com

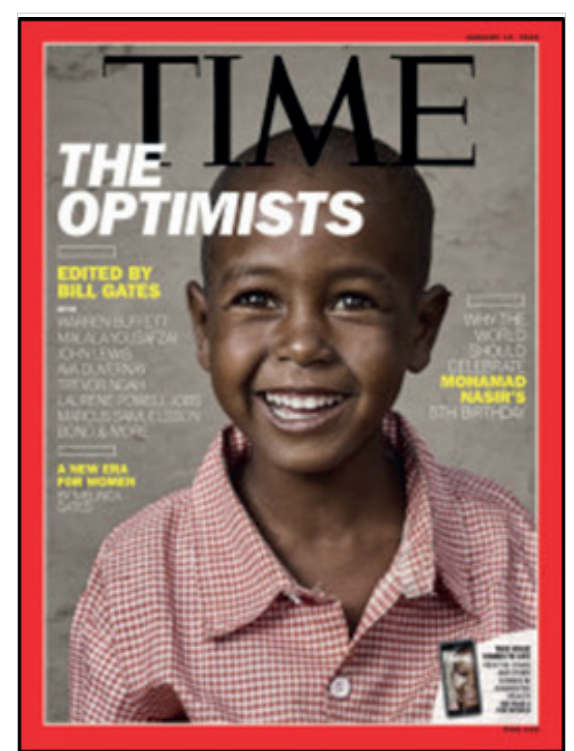

https://time.com
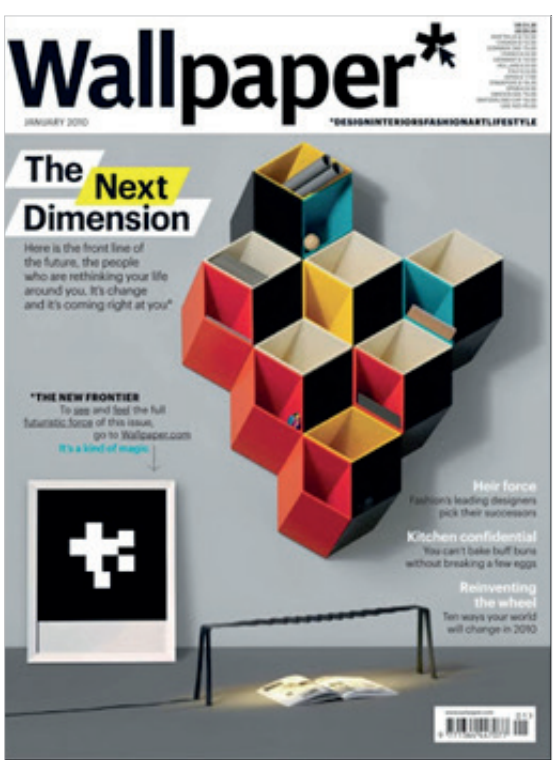

https://www.wallpaper.com
Image 2. AR experiences from Esquire, Time and Wallpaper magazines 
tions (Image 2). However, the possibilities of AR invoke other, more ambitious types of informative offerings that go beyond the merely illustrative stage to delve into the type and characteristics of the disseminated messages.

AR has been closely linked to immersive journalism (Nielsen; Sheets, 2019). However, immersive journalism predates the development of AR and its derivatives. The term "immersion" takes its meaning from technologies that offer a totally immersive user experience (Vaz; Tejedor, 2019). This is a type of journalism that, supported by interactive and visual technologies, is founded on the following communicative possibilities:

- an interface composition within a single framework;

- a realistic graphical style;

- continuous movement;

- ambient sound;

- a direct interaction system;

- permanent choices for the user;

- a continual ability to affect the plot of the story;

- a gamified strategy;

- the simulation of characters, settings, and actions; and

- a commitment to embodiment (Domínguez-Martín, 2015).

The emergence of mobile technology and its acceptance by young audiences constitute an incentive for the journalistic development of AR (Thornton, 2010; Hill, 2011). However, authors such as Meneses-Fernández and Martín-Gutiérrez (2016) have pointed out that, at a journalistic level, AR has mostly been used as a complement to printed or televised media messages, to the detriment of its potential as an "immersive" and "surprising" "entertainment" resource (Meneses-Fernández; Martín-Gutiérrez, 2016, p. 3). There are studies on some possible applications of this "easy and simple" technology for communication purposes (Pavlik; Britges, 2013, p. 43). Among the possibilities identified, the following stand out:

- interactive and geolocated, overlapping graphics;

- videos and photos with geosynchronization;

- QR codes as a guide for or to attract tourists;

- social networks through platforms including geolocation, and

- identification of information sources.

Despite this multiplicity of options, its journalistic use still resides in the current media landscape (Samson, 2015; Rubio-Tamayo et al., 2017) and many experiences are still inspired by the logic of the mashup (Tejedor-Calvo, 2007).

AR offers journalism renewed immersion proposals (De-la-Peña et al., 2010) through a set of possibilities that

"allow not only visual, but also sensory experience of a three-dimensional synthetic environment", Domínguez-Martín, 2013, p. 104).

The journalist must be able to choose between this set of narrative possibilities (López-Hidalgo, 2016), which includes the use of AR to generate journalistic content that connects with its users (Tran et al., 2019), especially in the current scenario marked by the prominence of mobile telephony (Liao, 2018). However, the possibilities of this technology in the journalistic field have not been studied in depth, from the conception and generation of messages to the competences and abilities demanded of the journalist.

AR demands new skills and abilities from journalism professionals, especially in a scenario marked by the permanent transformation of communication formats and the redefinition of information consumption habits (Romero-Rodríguez; Aguaded, 2016; 2017). The challenge of training for AR demands, on the one hand, a review and update of study plans (Jiujiang, 2018; Tejedor-Calvo; Cervi, 2017), the study of its training possibilities (Savela et al., 2020), and the promotion of media skills in the general public (Romero-Rodríguez; Contreras-Pulido; Pérez-Rodríguez, 2019).

The general objective of this research is to define and diagnose the state of AR in immersive journalism in order to determine its current state and the associated challenges and opportunities in the workplace. As mentioned above, the study has the following auxiliary objectives:

a) define the characteristic elements of $A R$;

b) establish the dynamics of journalistic content production that it introduces;

c) identify the transformative potential of AR in the construction of journalistic stories;

d) describe the benefits and weaknesses of this technology;

e) analyze its synergies and potential combinations with other types of technologies;

f) define the competences and abilities that AR demands from journalists; and

g) indicate which devices will contribute to the consolidation and development of AR. 


\section{Materials and methods}

This research has an exploratory scope and qualitative design, and focuses on exploring the terrain by analyzing and providing variables, dimensions, and indicators that are still under construction around the immersive journalism enabled by AR. The use of interviews as an exploratory method can provide information on a phenomenon that has not yet been addressed sufficiently in scientific literature, while also providing explanatory elements and indications of possible new prospective phenomena to serve as study variables in future research.

The information is verified by applying a methodological triangulation between semistructured interviews and documentary sources identified through a systematic review of the scientific literature, as part of the secondary research (Codina, 2017), which allows us to address the most important works on this topic (Ramírez-Montoya; García-Peñalvo, 2018).

This comparison of the theoretical foundations with the perceptions of professors, researchers, and well-established journalists who have used this technology, as well as professionals who have worked in the development of such applications, provides a sufficient context for the studied phenomena (Calvo-Rubio; Ufarte-Ruiz, 2020). In addition, professional praxis is collated with the results of previous research and expert opinions on the subject (Ramírez-Montoya; Lugo-Ocando, 2020), through practices that allow the interpretation of reality (Denzin; Lincoln, 2017).

\subsection{Instruments}

The in-depth, semistructured interview is useful to determine the perspectives of the interviewees, as well as their mental categories, interpretations, feelings, and prospects (Irvine; Drew; Sainsbury, 2012). Considering that this study was to be carried out with three different groups, three questionnaires were designed which, although coinciding in their objectives and variables (Table 2), differed in the wording of the proposals and in that each cluster included two or three different questions depending on the target profile.

Table 2. Thematic variables of the interviews

\begin{tabular}{|l|l|}
\hline \multicolumn{1}{|c|}{ Variable } & \multicolumn{1}{c}{ Description - Guiding questions } \\
\hline Essential characteristics & What are the basic elements present in AR? \\
\hline Transformation of routines & How have professional routines and practices changed? \\
\hline Content & What are the changes that this technology generates within journalistic narrative and production? \\
\hline Advantages & What are the contributions or benefits of including this technology in journalistic products? \\
\hline Disadvantages & What are the gaps that must be overcome for this technology to reach full development? \\
\hline Other innovations & What are the other technologies that augmented reality in journalism should be complemented by? \\
\hline Professional profiles & What are the characteristics required for a journalist specialized in AR? \\
\hline Technological devices & In your opinion, what are the technological devices that will increase the use of AR? \\
\hline
\end{tabular}

Additionally, and as a complement to the semistructured interview questionnaire, a survey instrument (Table 3 ) was designed with four multiple-choice questions, Likert scales, and ranking, to achieve greater precision on the dimensions and indicators derived from the qualitative section. These questions were posed to the ten interviewees as a complement to their qualitative responses. This instrument reports quantitative results that serve as validators of the former answers, thereby facilitating the extraction of results and findings.

Table 3. Content of the validation survey

\begin{tabular}{|c|c|}
\hline Question & Response type \\
\hline Do you think that future communication professionals who work with AR technology need specialized training? & $\begin{array}{l}\text { Simple selection } \\
\qquad(y / n)\end{array}$ \\
\hline $\begin{array}{l}\text { Rate the following characteristics of augmented reality technology according to their relevance: augmentation, } \\
\text { interactivity, portability, geolocation, immersion. }\end{array}$ & $\begin{array}{l}\text { Likert scale } \\
\qquad(1-5)\end{array}$ \\
\hline $\begin{array}{l}\text { Select three challenges for the development and research of augmented reality technology: } \\
\text { - Sociological and ethical studies of the impact of this technology applied to our daily lives } \\
\text { - Redefinition of interaction paradigms } \\
\text { - Development of sensing and actuation technologies } \\
\text { - Creation of new theories and models on augmented senses } \\
\text { - Experimental research on the use of augmented senses in humans } \\
\text { - Using AR in everyday systems and applications } \\
\text { - Other }\end{array}$ & $\begin{array}{l}\text { Multiple choice } \\
\qquad(\max .3)\end{array}$ \\
\hline $\begin{array}{l}\text { What would be your main concerns regarding the development of this technology? You can select more than } \\
\text { one: } \\
\text { - Use of data obtained by companies developing AR } \\
\text { - User's inability to distinguish false information given the nature of this technology } \\
\text { - Universal access to this technology } \\
\text { - Lack of professionals trained to use this technology } \\
\text { - Disinterest of users } \\
\text { - Other }\end{array}$ & Multiple choice \\
\hline
\end{tabular}




\subsection{Participants}

The aim of conducting this exploratory-qualitative study was not to generate inferences or induction reasoning, but rather to open a space for debate in which perceptions would not be restricted to strict theoretical categories. In this sense, the sampling strategy was created intentionally and based on judgment. The units were selected based on conceptual criteria only, in accordance with the principles of structural representativeness. Therefore, the variables specifying the structural composition of the sample were defined theoretically by the researcher (Mejía-Navarrete, 2000).

The intentional selection criteria were based on the roles of the subjects in the fields of journalism, innovation, and research (Ufarte-Ruiz; Peralta-García; Murcia-Verdú, 2018; Calvo-Rubio; Ufarte-Ruiz, 2020), exclusively in terms of the suitability and relevance of their profile. A total of 57 subjects were invited to participate in the investigation, of whom only 10 confirmed their intention to participate via electronic informed consent. These ten interviewees were sufficient to reach the saturation point -confirmed in the transcript- understood as the point at which the interviewees begin to repeat the responses of others (Callejo, 1998), thus the addition of more participants would not enrich this research process.

The interviews were conducted and processed telematically in the months of April and June 2020. In total, the effective sample (ES) was made up of four professors/researchers, three journalists with recognized experience in the use of this technology, and three people working on the development of AR applications. These three profiles are suitable, as they combine the field of academic research specialized in AR, journalistic practice (particularly in media that use this type of technology), and technical personnel who develop and implement it. Thus, the research approach is not limited only to the journalistic or investigative field, but is triangulated with the technological field, which is essential for this type of research.

\section{Results and discussion}

\subsection{Essential characteristics}

All of the interviewed experts agreed with the five theoretical categories of AR: augmentation, interactivity, portability, geolocation, and immersion (see examples in Table 4).

Table 4. Excerpts from the responses of the interviews on the characteristics of AR

E2: Augmented reality allows the user to immerse themselves in the story, generating greater engagement with the narrative.
E5: [...] you can take advantage of space, using geopositioning to interlace with information in the cloud.
E6: $[\ldots]$ is an immersive and interactive product. It allows you to play with the information, make it yours.

According to the interpretation of the answers and to construct a collective concept, augmented reality (AR) is a technology that enables greater interactivity with information, through both immersion and augmentation, taking advantage of the elements of portability, ubiquity, geolocation, and connection offered by mobile devices such as smartphones, tablets, and phablets. However, some experts, especially application developers, emphasized the gradual digitization of other platforms such as smartwatches, podcast applications, vehicles, and even some household appliances.

These responses were verified quantitatively using the second question of the survey to strengthen the attributes of each characteristic. In the evaluation hierarchy, the immersion characteristic was ranked first, while geolocation was rated with the lowest score (Graph 2).

\subsection{Transformation of practices and content}

The key element that makes some content successful is mainly the possibility of showing images to the viewer with high-quality graphics, which allows an appropriate setting of the information to be shown. On the other hand, academics, for the most part, alluded to technological elements such as: the use of the camera to capture the image of reality seen by the user; the physical platform on which the mixture of real and synthetic images is projected; the processing infrastructure that interprets the real-world information received by the user and generates the virtual content; and interactivity, between either the presenter or journalist and the audience, and other elements that make up the scene.

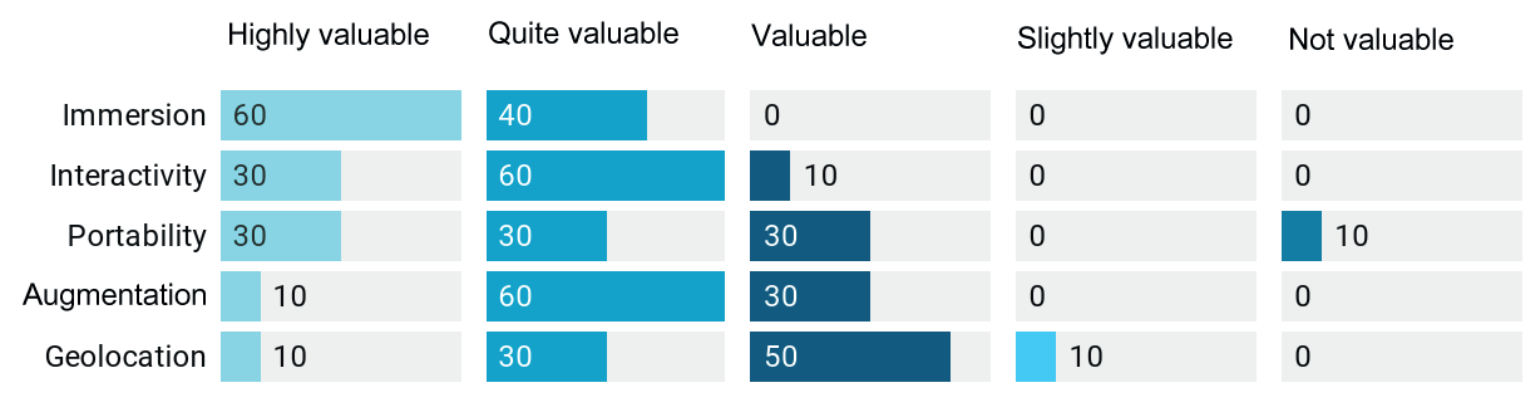

Graph 2. Expert assessment of the theoretical characteristics of AR 
Other elements highlighted by developers and media professionals included the following: imagination and creativity when presenting information, a choice of topics that engage and interest the reader, the use of technology to narrate in a way that would otherwise be impossible, and not requiring the user to have complex systems or other types of terminals. The Table 5 compiles some experiences that the interviewees considered to be successful.

Table 5. Successful experiences of AR in journalism, according to the interviewees

\begin{tabular}{|c|c|}
\hline Experience & Explanation \\
\hline The Weather Channel & $\begin{array}{l}{[\ldots] \text { was the starting point for the popularization of augmented reality, since it pioneered the }} \\
\text { use of this technology to transfer information about meteorological phenomena such as hurri- } \\
\text { canes or floods, managing to put the spotlight on a resource that was still somewhat unknown } \\
\text { to society. }\end{array}$ \\
\hline $\begin{array}{l}\text { Grupo Atresmedia } \\
\text { Audiovisual Innovation Laboratory of RTVE } \\
\text { EiTB } \\
\text { Telemadrid } \\
\text { TV3 }\end{array}$ & $\begin{array}{l}\text { [...] have been pioneers in Spain of the use of augmented reality in news programs and regu- } \\
\text { lar programming; even regional televisions have begun to experiment with these formats. }\end{array}$ \\
\hline The New York Times (NYT app) & $\begin{array}{l}\text { E4: The integration of augmented reality formats in the NYT app has allowed us to advance } \\
\text { towards the future of the journalistic narrative. } \\
\text { E9: [...] NYT, with the coronavirus, has made a simulation for the calculation of social distances } \\
\text { through a three-dimensional simulation where each person visualizes their own space. The } \\
N Y T \text { is a reference point, providing a vision of the future of immersive journalism. }\end{array}$ \\
\hline Time Immersive (app) & $\begin{array}{l}{[\ldots] \text { includes content on the Amazon or the Apollo } 11 \text { mission (moon landing) that are audio- }} \\
\text { visual pieces, in print-digital format, that combine three-dimensional re-creation, immersion, } \\
\text { and interactivity. Despite the simple navigation mechanism, this provides meaning to the } \\
\text { narrative experience. }\end{array}$ \\
\hline Non-fiction narratives (documentaries) & $\begin{array}{l}\text { Although not journalistic content per se, immersive documentaries, such as Notes on the blind- } \\
\text { ness, The drawing room, or Chronicle of a city that was, are stories that are narrated by taking } \\
\text { advantage of the interactivity with the audience. }\end{array}$ \\
\hline
\end{tabular}

When asked about which types of content are appropriate or suitable to be enriched with AR in a transversal way, the interviewees agreed that augmented reality is applicable to any content, as long as it is conceived as a tool at the service of journalism and not as a significant element in and of itself. Along these lines, they considered it appropriate to apply it to topics that require the spatial experience of three-dimensionality, to facilitate understanding of the reality communicated.

The interviewees point out that augmented reality offers a wide variety of possibilities for use in various sections, such as sports, political, social, local, and cultural or meteorological information and, ultimately, any content that requires contextualization or spatial orientation by the viewer or a complex presentation of technical data/content.

\subsection{Advantages and disadvantages of the application of AR}

The interviewees offered very dissimilar but enriching answers on the pros and cons of using AR to enrich journalistic narratives. The main advantages are listed in Table 6.

Table 6. Advantages of the use of AR in the journalistic narrative

\begin{tabular}{|l|l|l|l|}
\hline Information simplification & Dynamism & Active audience & Interaction and closeness \\
\hline $\begin{array}{l}\text { Familiarization with complex } \\
\text { concepts }\end{array}$ & $\begin{array}{l}\text { Integration into the physical } \\
\text { space and geolocation }\end{array}$ & Personalization of content & Sensory experience \\
\hline Impact and spectacular nature & $\begin{array}{l}\text { Monopoly of attention to the } \\
\text { narrative }\end{array}$ & $\begin{array}{l}\text { Greater engagement with the } \\
\text { audience }\end{array}$ & Accessibility \\
\hline $\begin{array}{l}\text { Assimilation of large volumes of } \\
\text { data }\end{array}$ & $\begin{array}{l}\text { Intuitive and interactive infogra- } \\
\text { phics }\end{array}$ & $\begin{array}{l}\text { Promoting the creativity of } \\
\text { journalists }\end{array}$ & Real-time data updates \\
\hline
\end{tabular}

Increased digital traffic and con-

tent profitability

Of course, like all emerging technologies, AR applied to journalism must overcome obstacles that do not allow it to reach its current full development and integration in the journalistic field, such as those presented in Table 6.

Table 6. Disadvantages of the use of AR in journalism

\begin{tabular}{|l|l|l|l|}
\hline $\begin{array}{l}\text { High economic cost of implemen- } \\
\text { ting the technology }\end{array}$ & $\begin{array}{l}\text { Specialized training for the deve- } \\
\text { lopment of AR }\end{array}$ & $\begin{array}{l}\text { Users' digital divide and fear of } \\
\text { certain apps }\end{array}$ & $\begin{array}{l}\text { Time planning to produce narra- } \\
\text { tive formats }\end{array}$ \\
\hline $\begin{array}{l}\text { Lack of qualified staff in news- } \\
\text { rooms }\end{array}$ & $\begin{array}{l}\text { Requirement that the audience } \\
\text { have an up-to-date terminal or } \\
\text { interface }\end{array}$ & $\begin{array}{l}\text { Lack of knowledge about } \\
\text { screenwriting and storytelling }\end{array}$ & $\begin{array}{l}\text { Lack of business commitment to } \\
\text { these formats }\end{array}$ \\
\hline $\begin{array}{l}\text { The benefits and returns of AR for } \\
\text { web traffic are not so clear }\end{array}$ & High workload & &
\end{tabular}




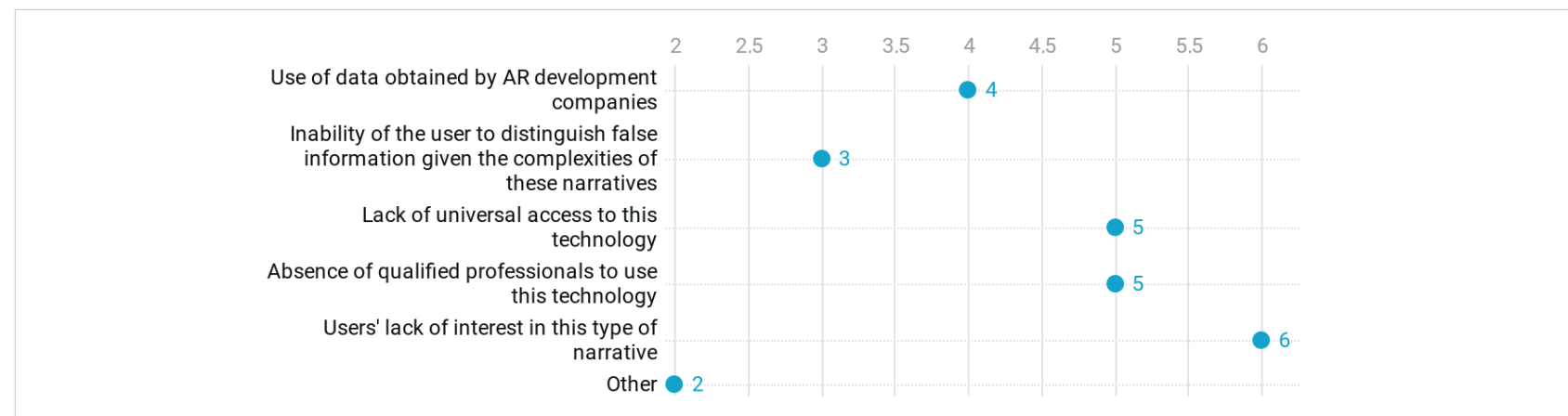

Graph 3. Expert assessment of the main obstacles to the application of AR

The fourth question of the survey (Table 2) sought to ratify the emerging variables on the obstacles of applying this technology in the journalistic narrative, to complement and prioritize which aspects must be addressed to implement AR in the journalistic narrative (Graph 3).

As seen in Graph 3, most experts consider that this technology, despite enriching journalistic narratives, does not attract sufficient interest from the audience. This lack of interest means that AR is not a priority investment for many media companies. In addition, the digital divide, based on the need to have medium/high-end devices to access this technology, and the lack of professionals trained for this type of development, are other main obstacles that have made its consolidation impossible.

It is also important to note that, within the option "others," the limitations expressed by experts included the high consumption of mobile data and the algorithms of social networks that do not favor this type of technology.

\subsection{Technologies that should complement AR}

Experts agree that the emergence of $5 \mathrm{G}$ technology, which will allow browsing at speeds of up to 10 Gbps (Gigabit per second), will definitely boost augmented reality, making its application in the journalistic narrative less and less exceptional, especially in a communicative ecosystem based on competition for audience attention. This is also complemented by the fact that interviewees from the AR application development sector considered that the current network (4G) limits the possibilities of augmented reality; for example, when AR agencies seek to create tools, they are forced to work in offline environments that can only load processes from internal memory but not from the cloud (cloud computing).

Another benefit of the introduction of $5 \mathrm{G}$ that app developers consider important is the improvement in latency, which will directly affect response times, allowing connection to the cloud in almost real time, meaning that the immersive experience will no longer be unstable. Finally, advancements in machine learning, big data, and artificial intelligence (AI) will also help AR take off. Systems will have the ability to correctly interpret external data to learn from it and use it to achieve specific tasks and goals through flexible adaptation.

On the other hand, the interviewees from the academic and professional-journalistic sector considered that the technologies that could complement AR are virtual reality, 360 videos, transmedia narratives, and elements of visual scenery, such as large concave LED screens, reflective floors, or circular sets, among others. Experts pointed out the challenges to the development and research of AR technology to be used in conjunction with other technologies (Figure 4), taking into consideration the main emerging technologies from Gartner's Hype cycle (Figure 1).

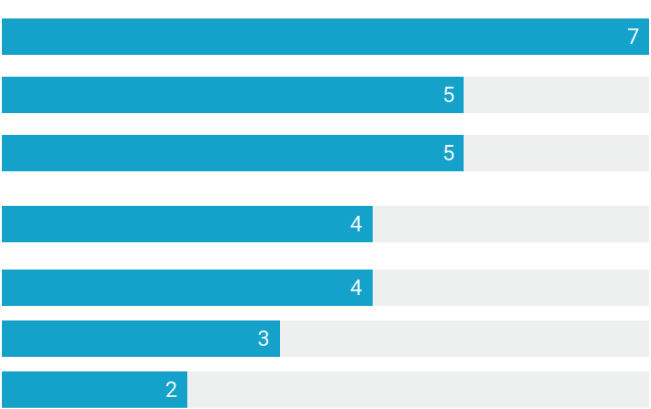

Graph 4. Challenges, technologies, and emerging areas in AR 


\subsection{Competences, skills, and professional profiles}

Another specific objective of this research is to determine the training challenges for journalists to adapt to the technologies reviewed in the previous section. In this regard, $80 \%$ of those interviewed considered that information professionals should receive specialized training in order to undertake narrative projects in these formats. They also highlight the lack of staff trained in these matters in newsrooms. According to the interviewees, communication faculties must activate mechanisms that allow (Tejedor-Calvo; Cervi, 2017):

- for their study plans to be updated and verified, and

- for their teaching staff to be retrained.

The new student profile is directly connected with this training strategy, which should thus consider this new profile as well as the link between students and technology (Romero-Rodríguez; Aguaded, 2016, 2017), meaning that universities and training centers must work hand in hand with (or even anticipate) emerging technologies, since the profile of graduates and their entrepreneurial skills must match the demands of the labor market.

However, experts agreed that tools or technical skills are necessary, not only for the development of new immersive experiences but also for learning how to reformulate existing narrative strategies into these new formats, i.e., learning to script them. This ability complements the need for journalists to know which type of information can be represented through interactive infographics, animations, 360 videos, and geolocation, among others. This means that, although the technological skills of computer development and programming will become increasingly necessary, professionals who know how to adapt information to different narrative formats and convert data into stories and thence into graphical, audiovisual, and immersive representations will be even more important. In short, such content development invites us to reflect on the value that AR brings to the story we want to tell.

Regarding the competences that every journalist acquires in their academic and professional training, experts highlighted curiosity, ethics, persistence, trust, teamwork, and respect for sources and the viewer. In any case, in the case of working with AR, aspects such as versatility, creativity, analytical and synthetic capacity, creativity, and the identification of new stories are indispensable qualities for a communications professional working with this technology.

\section{Conclusions}

Augmented reality (AR) combines a series of possibilities (especially interactivity, portability, geolocation, and immersion) with great potential for the conception and development of journalistic content. Of these, however, the ability to give users a leading role is particularly interesting. This potentiality, which was already possible, is now clearly reinvented and its scope widened. The interactive component is directly linked to the construction of immersive experiences, an aspect that should be an object of study and project ideation in both academia and industry.

The little importance that experts give to geolocation also invites a reflection on the role of this possibility in AR developments, given the very wide use of interactive maps in the main applications and websites in different sectors. This aspect demands study and works that analyze the links between hypermedia cartography and the telling of informative stories. In the same way, research highlights the need to improve processes and devices to guarantee high-quality images and graphics for the creation of journalistic messages.

In short, AR surpasses conventional screens (desktops and laptops) by being projected onto other types of mobile devi$\mathrm{ce}$, thus demanding that journalists be able to devise messages for presentation on very different platforms.

We are, therefore, facing a technology that is capable of transforming communication processes at a general level. Journalism can take advantage of this opportunity and enrich the sector with the features of AR that, although they can address all the human senses of perception, also require a combination of reality and virtuality (Maquillón-Sánchez; Mirete; Avilés, 2017). This aspect affects the production processes of journalistic content and impacts current production practices. This study emphasizes the need to reinvent the approach and conception of journalistic stories so that AR does not play a testimonial or decorative role, but instead assumes an important role in the conception of novel and even disruptive journalistic formats, always within the guidelines of the journalistic profession of rigorous, contextualized, and accurate information.

Although experts pointed out that AR can be applied in any area or subject area, they warn of the risk of falling into approaches that only incorporate this technology as a significant feature in and of itself. Therefore, this research opens the possibility of studies that address these issues and, in particular, the most appropriate approaches whereby the spatial experience of three-dimensionality facilitates better understanding of the reality to be communicated, or those that demand a contextualization or orientation of the user within a complex scene.
Versatility, creativity, analytical and synthetic capacity, creativity, and the identification of new stories are indispensable qualities for a communications professional working with $A R$ 
Despite its many possibilities, AR has not attracted wide interest among Internet users. This aspect, which is identified as one of the main weaknesses, requires extra work, including on the one hand, the need to inform users of the benefits of this technology and, on the other, the importance of persuading the industry of the relevance of making investments and developments in this field. Added to this is the digital divide that, from an instrumental point of view, excludes certain groups due to the need to acquire upper/middle-range equipment to access this type of development. The emergence of $5 \mathrm{G}$ technology may therefore be a development that redefines the application scenario and the degree of access and acceptance of AR. The need to work in offline environments, due to connectivity limitations, demands new work and studies to promote the use of cloud computing or other scenarios that will enable the promotion of AR.

This study, based on the emerging technologies identified by Gartner's Hype cycle, reveals the connection between AR and other technological developments. AR will need to rely on other technologies (such as virtual reality, 360 videos, transmedia narratives, and elements of visual scenery such as large concave LED screens, among others) to be able to offer high-quality journalistic developments. In addition, the industry that is focused on application development is seen as a decisive ally in the definitive establishment of AR in the journalistic field, as well as developments in the field of machine learning, Big Data, and artificial intelligence. The consolidation of AR as a journalistic technology will depend on a series of aspects that, from a systemic approach, must contribute to building a more conducive context. Together with the democratization of access to peripherals and necessary technological elements, the promotion of media competences in citizens (Romero-Rodríguez; Contreras-Pulido; Pérez-Rodríguez, 2019) also constitutes a decisive milestone for the consolidation of AR in journalism.

\section{References}

Aronson-Rath, Raney; Milward, James; Owen, Taylor; Pitt, Fergus (2017). Virtual reality journalism. Towcenter for digital journalism. New York: Columbia University.

https://www.cjr.org/tow_center_reports/virtual_reality_journalism.php

Azuma, Ronald T. (2017). "Making augmented reality a reality". Applied industrial optics: Spectroscopy, imaging and metrology. San Francisco, California, 26-29 June, paper JTu1F.1. ISBN: 9781943580293

Benítez-de-Gracia, María-José; Herrera-Damas, Susana (2018). "El reportaje inmersivo en vídeo 360: diseño de un modelo de análisis". El profesional de la información, v. 27, n. 1, pp. 149-161.

https://doi.org/10.3145/epi.2018.ene.14

Callejo, Javier (1998). "Los límites de la formalización de las prácticas cualitativas de investigación social”. Sociológica. Revista de pensamiento social, n. 3, pp. 93-119.

https://ruc.udc.es/dspace/handle/2183/2707

Calvo-Rubio, Luis-Mauricio; Ufarte-Ruiz, María-José (2020). “Percepción de docentes universitarios, estudiantes, responsables de innovación y periodistas sobre el uso de inteligencia artificial en periodismo". El profesional de la información, v. 29, n. 1, e290109.

https://doi.org/10.3145/epi.2020.ene.09

Caswell, David; Dörr, Konstantine (2017). “Automated journalism 2.0. Event-driven narratives”. Journalism practice, v. 12, n. 4, pp. 477-496.

https://doi.org/10.1080/17512786.2017.1320773

Codina, Lluís (2017). "Revisiones bibliográficas y cómo llevarlas a cabo con garantías: systematic reviews y Salsa Framework". Lluís Codina, 20 abril.

https://www.lluiscodina.com/revision-sistematica-salsa-framework

Crusafon, Carmina (2017). "Más allá de la realidad inmersiva". El periódico, 9 enero.

https://www.elperiodico.com/es/opinion/20170109/mas-alla-de-la-realidad-inmersiva-carmina-crusafon-5733052

De-la-Peña, Nonny; Weil, Peggy; Llobera, Joan; Giannopoulos, Elias; Pomés, Ausiàs; Spaniang, Bernhard; Friedman, Doron; Sánchez-Vives, María V.; Slater, Mel (2010). "Immersive journalism: Immersive virtual reality for the first-person experience of news". Presence: Teleoperators and virtual environments, v. 19, n. 4, pp. 291-301.

https://doi.org/10.1162/pres_a_00005

Denzin, Norman K.; Lincoln, Yvonna S. (2017). The SAGE handbook of qualitative research. Newcastle: SAGE Publications. ISBN: 9781412974172 
Domínguez-Martín, Eva (2012a). Periodismo inmersivo: Fundamentos para una forma periodística basada en la interfaz y la acción. Tesis doctoral. Barcelona: Universitat Ramon Llull. https://www.tesisenred.net/handle/10803/108956

Domínguez-Martín, Eva (2012b). Medios de comunicación masiva. México: Red Tercer Milenio. ISBN: 9786077331476

Domínguez-Martín, Eva (2013). Periodismo inmersivo. La influencia de la realidad virtual y del videojuego en los contenidos informativos. Barcelona: Editorial UOC. ISBN: 9788490297766

Domínguez-Martín, Eva (2015). “Periodismo inmersivo o cómo la realidad virtual y el videojuego influyen en la interfaz e interactividad del relato de actualidad". El profesional de la información, v. 24, n. 4, pp. 413-423.

https://doi.org/10.3145/epi.2015.jul.08

Flavián, Carlos; Ibáñez-Sánchez, Sergio; Orús, Carlos (2019). "The impact of virtual, augmented and mixed reality technologies on the customer experience". Journal of business research, v. 100, pp. 547-560.

https://doi.org/10.1016/j.jbusres.2018.10.050

FTI (2020). Trends report for entertainment, media \& technology. Future Today Institute. https://futuretodayinstitute.com

Fundación Telefónica (2011). Realidad aumentada: una nueva lente para ver el mundo. Madrid: Ariel.

Galeano, Susana (2018). "Los 7 principios del transmedia de Henry Jenkins". Marketing4ecommerce, 30 August. https://marketing4ecommerce.net/principios-transmedia-henry-jenkins

Guizzo-Da-Rocha, Giovanni (2016). “Jornalismo imersivo: exploraçoes e caminhos para apropiações do acontecimento jornalístico a partir de experiências com dispositivos de realidade virtual”. In: XVII Congresso de ciências da comunicação na Região Sul. Curitiba, 26-28 maio.

https://www.portalintercom.org.br/anais/sul2016/resumos/R50-1919-1.pdf

Hill, Retha (2011). "What augmented reality can do for the media industry". MediaShift, June 14. http://mediashift.org/2011/06/what-augmented-reality-can-do-for-the-media-industry165

Irvine, Annie; Drew, Paul; Sainsbury, Roy (2012). “'Am I not answering your questions properly?' Clarification, adequacy and responsiveness in semi-structured telephone and face-to-face interviews". Qualitative research, v. 13, n. 1, pp. 87106.

https://doi.org/10.1177/1468794112439086

Jenkins, Henry (2008). Convergence culture: Where old and new media collide. Barcelona: Paidós Ibérica. ISBN: 9780 814742952

Kool, Hollis (2016). "The ethics of immersive journalism: A rethorical analysis of news storytelling". Intersect: The Stanford journal of science, technology, and society, v. 9, n. 3.

https://ojs.stanford.edu/ojs/index.php/intersect/article/view/871

Larrondo-Ureta, Ainara; Fernandes-Teixeira, Juliana (2016). "La convergencia narrativa en el periodismo móvil. Aproximación a la integración del contenido audiovisual en los productos nativos para iPad". Estudios sobre el mensaje periodístico, v. 22, n. 2, pp. 777-792.

https://doi.org/10.5209/ESMP.54235

Liao, Tony (2018). "Future directions for mobile augmented reality research: Understanding relationships between augmented reality users, nonusers, content, devices, and industry". Mobile media communication, v. 7, n. 1, pp. 131-149. https://doi.org/10.1177/2050157918792438

López-García, Xosé; Pereira-Fariña, Xosé (2010). Convergencia digital. Reconfiguración de los medios de comunicación en España. España: Universidad Santiago de Compostela. ISBN: 9788498873795

López-Hidalgo, Antonio (2016). "El periodismo que contará el futuro". Chasqui. Revista latinoamericana de comunicación, n. 131, pp. 239-256. ISBN: 9788498873795

https://revistachasqui.org/index.php/chasqui/article/view/2733/pdf

Mañas-Viniegra, Luis; Veloso, Ana-Isabel; Sierra-Sánchez, Javier (2020). “Contenidos inmersivos violentos: investigación con eye tracking en jóvenes universitarios en España y Portugal”. El profesional de la información, v. 29, n. 1, e290108. https://doi.org/10.3145/epi.2020.ene.08

Maquillón-Sanchez, Javier; Mirete, Ana-Belén; Avilés, Marina (2017). “La realidad aumentada (RA). Recursos y propuestas para la innovación educativa". Revista electrónica interuniversitaria de formación del profesorado, v. 20, n. 2, pp. 183-203.

https://doi.org/10.6018/reifop/20.2.290971 
Mejía-Navarrete, Julio (2000). “El muestreo en la investigación cualitativa”. Investigaciones sociales, v. 4, n. 5, pp. 165180.

https://doi.org/10.15381/is.v4i5.6851

Meneses-Fernández, María-Dolores; Martín-Gutiérrez, Jorge (2016). "Medios de comunicación impresos y realidad aumentada, una asociación con futuro". Arbor, v. 192, n. 777, pp. 292-304.

https://doi.org/10.3989/arbor.2016.777n1008

Milgram, Paul; Kishino, Fumio (1994). "A taxonomy of mixed reality visual displays". leice transactions on information and systems, v. 77, n. 12, pp. 1321-1329.

https://cs.gmu.edu/ zduric/cs499/Readings/r76JBo-Milgram_IEICE_1994.pdf

Muñoz-Saavedra, Luis; Miró-Amarante, Lourdes; Domínguez-Morales, Manuel (2020). "Augmented and virtual reality evolution and future tendency". Applied sciences, v. 10, n. 1.

https://doi.org/10.3390/app10010322

Nielsen, Soren-Lund; Sheets, Penelope (2019). "Virtual hype meets reality: Users' perception of immersive journalism". Journalism, online first.

https://doi.org/10.1177/1464884919869399

Panetta, Kasey (2019). “Gartner top 10 strategic technology trends for 2020”. Smarter with Gartner, October 21. https://www.gartner.com/smarterwithgartner/gartner-top-10-strategic-technology-trends-for-2020

Parra-Valcarce, David; Edo-Bolós, Concha; Marcos-Recio, Juan-Carlos (2017). “Análisis de la aplicación de las tecnologías de realidad aumentada en los procesos productivos de losmedios de comunicación españoles". Revista latina de comunicación social, n. 72, pp. 1.670-1.688.

https://doi.org/10.4185/RLCS-2017-1240

Pavlik, John V.; Britges, Frank (2013). "The emergence of augmented reality (AR) as a storytelling medium in journalism". Journalism \& comunication monographs, v. 15, n. 1, pp. 4-59.

https://doi.org/10.1177/1522637912470819

Peñafiel-Saiz, Carmen (2016). "Reinvención del periodismo en el ecosistema digital y narrativas transmedia”. AdComunica: Revista científica de estrategias, tendencias e innovación, n. 12, pp. 163-182.

http://repositori.uji.es/xmlui/handle/10234/167719

Pérez-Seijo, Sara; López-García, Xosé (2017). "El periodismo inmersivo en las televisiones públicas europeas". En: I Congreso internacional da Asociación Galega de Investigadores e Investigadoras en Comunicación. Santiago: Universidad de Santiago de Compostela, pp. 809-829.

https://www.agacom.org/actas-agacom

Prendes-Espinosa, Carlos (2015). "Realidad aumentada y educación: análisis de experiencias prácticas”. Pixel-bit. Revista de medios y educación, n. 46, pp. 187-203.

https://doi.org/10.12795/pixelbit.2015.i46.12

Raskar, Ramesh; Welch, Greg; Fuchs, Henry (1998). "Spatially augmented reality”. In: First IEEE Workshop on augmented reality, pp. 11-20.

https://www.cs.unc.edu/ welch/media/pdf/IWAR_SAR.pdf

Romero-Rodríguez, Luis M.; Aguaded, Ignacio (2016). “Consumption of information and digital competencies of journalism students from Colombia, Peru and Venezuela". Convergencia. Revista de ciencias sociales, n. 70, pp. 1-20.

https://convergencia.uaemex.mx/article/view/4171

Romero-Rodríguez, Luis M.; Aguaded, Ignacio (2017). "Toward a taxonomy of newspaper information quality: An experimental model and test applied to Venezuela dimensions found in information quality". Journalism, v. 18, n. 10, pp. 1327-1345.

https://doi.org/10.1177/1464884916663596

Romero-Rodríguez, Luis M.; Contreras-Pulido, Paloma; Pérez-Rodríguez, María-Amor (2019). “Media competencies of university professors and students. Comparison of levels in Spain, Portugal, Brazil and Venezuela". Culture and education, v. 31, n. 2, pp. 326-368.

https://doi.org/10.1080/11356405.2019.1597564

Rubio-Tamayo, José-Luis; Gértrudix-Barrio, Manuel; García-García, Francisco (2017). “Immersive environments and virtual reality: Systematic review and advances. Communication, interaction and simulation". Multimodal technologies and interaction, v. 1, n. 4, pp. 1-21.

https://doi.org/10.3390/mti1040021 
Samson, Eric (2015). "Informar con juegos serios: sus potenciales y limitaciones para el periodismo actual". Radar, v. 1, pp. 120-149.

https://doi.org/10.18272/posts.v1i1.239

Savela, Niina; Oksanen, Atte; Kaakinen, Markus; Noreikis, Marius; Xiao, Yu (2020). "Does augmented reality affect sociability, entertainment, and learning? A field experiment". Applied sciences, v. 10, n. 4, pp. 1-15.

https://doi.org/10.3390/app10041392

Stein, Scott; Shew, Ian (2019). "Why AR is going to give you 'Superpowers' in the future". Cnet, February 28. https://www.cnet.com/news/the-future-of-ar-according-to-microsoft/

Tejedor-Calvo, Santiago (2006). La enseñanza del ciberperiodismo en las licenciaturas de periodismo en España. Zamora: Comunicación Social. ISBN: 9788496082465

Tejedor-Calvo, Santiago (2007). “Periodismo 'mashup'. Combinación de recursos de la web social con una finalidad ciberperiodística”. Anàlisi: quaderns de comunicació i cultura, n. 35, pp. 17-26.

https://www.raco.cat/index.php/Analisi/article/view/74252

Tejedor-Calvo, Santiago; Cervi, Laura (2017). "Análisis de los estudios de Periodismo y Comunicación en las principales universidades del mundo. Competencias, objetivos y asignaturas". Revista latina de comunicación social, n. 72, pp. 1.626-1.647.

https://doi.org/10.4185/RLCS-2017-1238

Thornton, Therri (2010). "Augmented reality invades newsrooms, kids's show, ads". In: Glaser, Mark (ed.). MediaShift. Arlington: Public Broadcasting Service (PBS).

http://mediashift.org/2010/11/augmented-reality-invades-newsrooms-kids-shows-ads314

Tran, Huyen T. T.; Ngoc, Nam P.; Pham, Cuong T.; Jung, Yong-Ju; Thang, Truong-Cong (2019). “A subjective study on user perception aspects in virtual reality". Applied sciences, v. 9, n. 16, pp. 1-19.

https://doi.org/10.3390/app9163384

Ufarte-Ruiz, María-José; Peralta-García, Lidia; Murcia-Verdú, Francisco-José (2018). “Fact checking: un nuevo desafío del periodismo". El profesional de la información, v. 27, n. 4, pp. 733-741.

https://doi.org/10.3145/epi.2018.jul.02

Vaz, Martín; Tejedor-Calvo, Santiago (2019). “Aproximación conceptual al periodismo inmersivo: reflexiones a partir del estudio de caso de seis proyectos periodísticos". Revista ibérica de sistemas y tecnologías de la información, n. 20, pp. 100-112.

https://search.proquest.com/openview/4c6b96a5a68f083c0bb515d78d0e0b61/1

Vázquez-Herrero, Jorge; López-García, Xosé (2016). "Documental interactivo en los cibermedios: estudios de caso de 2012 a 2016". En: Rúas-Araújo, José; Martínez-Fernández, Valentín-Alejandro; Rodríguez-Fernández, María-Magdalena; Puentes-Rivera, Iván; Yaguache-Quichimbo, Jenny; Sánchez-Amboage, Eva (eds.). De los medios y la comunicación de las organizaciones a las redes de valor. Actas del II Simposio de la Red Internacional de Investigación y Gestión de la Comunicación, Ecuador.

https://dialnet.unirioja.es/servlet/articulo?codigo $=6073688$

Veel, Kristin (2018). "Make data sing: The automation of storytelling". Big data \& society, v. 5, n. 1. https://doi.org/10.1177/2053951718756686

Villa-Montoya, María-Isabel (2018). “Narrativas Inmersivas para comunicadores. Realidad virtual, aumentada y mixta en propuestas audiovisuales de ficción y no ficción". Comunicación, n. 39, pp. 7-12.

https://doi.org/10.18566/comunica.n39.a01

Watson, Zillah (2017). VR for news: The new reality? Digital News Report. http://www.digitalnewsreport.org/publications/2017/vr-news-new-reality

Webb, Andrew (2018). 2018 Tech trends for journalism and media. Future Today Institute. https://futuretodayinstitute.com/2018-tech-trends-for-journalism-and-media

Webb, Andrew (2019). Tech trends. The Future Today Institute's annual report. Future Today Institute. https://futuretodayinstitute.com/2019-tech-trends/

Yoon, So-yeon; Tilanka, Chandrasekera (2015). "Adopting augmented reality in design communication: Focusing on improving spatial abilities". The international journal of architectonic, spatial, and environmental design, v. 9, n. 1, pp. 1-14. https://doi.org/10.18848/2325-1662/CGP/v09i01/38384 